\section{Starting date}

In ET39 (Jul 94), p. 45, 'What shall we call the decades of the twentyfirst century?' by John Algeo, I found a small mistake.

According to the U.S. Naval Observatory, the 20th century ends 31 December 12:00 p.m. the year 2000, not as John Algeo indicates 1999. The twenty first century starts 1 January 2001.

John Algeo has a good idea, but a year too soon. A decade would run from years 1 through 10 . Yours in the twentieth century,

Bob Degerberg, Gladwyne, Pennsylvania, U.S.A.

\section{Liége or Liège?}

In his article 'Axing the accent' (ET38, Apr 94), Adrian Room finds it curious that the spelling Liége often appears on English maps. This form of the name, which does indeed seem to defy all known rules of accentuation, should not, however, surprise him, since it is the traditional spelling of the Belgians themselves. Although it officially became Liège as long ago as 1946, many older Liégeois have, predictably, remained attached to the acute accent.

Mary Munro-Hill, Driffield, Yorkshire, England

\section{Wicked: 1}

The usage of "wicked" and "good" (ET39, Jul 94, p. 18) reminds me of the following from the Toronto 'Globe and Mail':

Among the idiosyncrasies of

Readers' letters are welcomed.

ET policy is to publish as representative and informative a selection as possible in each issue. Such correspondence, however, may be subjected to editional adaptation in order to make the most effective use of both the letters and the space available.
Nova Scotia dialect is the use of "good" in the scale of merit. An object or person can be described - in ascending order - as good, some good, right some good or right some Jesus good.

On that scale, Down Home is right some good.

"Down Home" or "Down East" is the Maritimes - near Maine, so I guess East is East.

Margaret Toth, Toronto, Ontario, Canada

\section{Wicked: 2}

I have a couple of comments to add to discussions in ET39 (Jul 94). First, In Kaleidoscope, Dale Roberts cites the L. L. Bean catalog use of what he implies is a Maine intensifier, "wicked." I would like to point out that the term has been in widespread usage throughout New England for quite a long time, I can recall, as a boy growing up in Vermont more than half a century ago, hearing a charming and attractive woman described as "wicked nice," a good horse called "wicked fast," etc. The word is usually pronounced with fairly tense vowels and nearly level stress: /wikid/.

Second, in News (France at War with Foreign Tongues), one may observe that the French government may wage whatever battles it wishes with borrowings and "Franglais," but as the clippings I brought home from Nice (NiceMatin) this summer will testify, the French will do pretty much as they please in the matter. The air controllers' strike produced "un très long weekend" even in the headlines, while citizens of Nice "bronzed" themselves in the sun.

William E. Bettridge, Associate Professor of English, University of Maryland Baltimore County, Baltimore, U.S.A.

\section{Is American better?}

Beneath your Comment Column, it states "ET leaves unchanged the orthography (normally British or American), and the usage of the individual contributors, although the editorial style of the magazine itself is that of Cambridge University Press."

When Noah Webster compiled his dictionary, spellings such as color, labor, and center were neither British nor American but merely alternatives. The only new spelling that he introduced was mold for mould.

On the face of it, the so-called American spellings are superior. Is there any reason to suppose that the so-called British spellings are, in fact, better? If the "British" cannot be shown to be better, might I suggest that the "American" be adopted for the style of the international review of the English language?

You might conduct a survey among your readership to see what it thinks.

Robert Craig, Weston-super-Mare, Avon, England

\section{Nigerian innovation}

As one who spent a number of years living in Nigeria, I enjoyed the article by Edmund O Bamiro on innovation (ET39, Jul 94). I used to collect examples of ellipsis when I was there, my favourite being the gradual reduction in description of highway accidents from "A GHASTLY ACCIDENT", to "ANOTHER GHASTLY ACCIDENT," to, finally, "ANOTHER GHASTLY."

Dr Philip C. Stine, Director,

Translation, Production, and Distribution Services, United Bible Societies, Reading, Berkshire, England 